Hikmah: Journal of Islamic Studies, 16 (2), 2020, 185-202

http://journal.uinjkt.ac.id/index.php/HIKMAH

DOI: 10.47466/hikmah.v16i2.174 | P-ISSN. 2088-2629, E-ISSN. 2581-0146

\title{
KEDUDUKAN FATWA DI NEGARA MUSLIM: INDONESIA, BERUNAI DARUSSALAM, MALAYSIA, MESIR
}

\author{
M. Zainul Hasani Syarif \\ UIN Syarif Hidayatullah Jakarta \\ zainulsyarif94@gmail.com
}

\begin{abstract}
Muslims will face many complex problem. They need solution to overcome. When Prophet Muhammad lived, all the problem either worldly or heavenly, were attributed to him. But after his death, the role of the companions, successor and ulamas at that time were such fatwa giver/council. It continues today. So, council of fatwa has significant position, dealing with religious affairs and also state-nation problems. They will be a reference to solve the problems. The position of the fatwa council is different in every muslim countries. It also influenced to the products of fatwa.
\end{abstract}

Keywords: Position; Fatwa; Muslim Countries

\begin{abstract}
Abstrak
Dari hari ke hari permasalahan yang dilami oleh ummat Islam khususnya semakin kompleks sehingga membutuhkan solusi yang tepat untuk mengatasinya. Saat Nabi Muhammad masih hidup, semua urusan baik yang bersifat duniawi, terlebih yang menyangkut ukhrawi langsung disandarkan sepenuhnya kepadanya. Namun beda halnya setelah ia wafat maka peran sahabat, tabi'in, ulama atau sejenis majelis fatwa kemudian menjadi estafet dalam melanjutkan tradisi sebagaimana yang telah dicontohkan oleh Nabi sebelumnya. Itulah maka majelis fatwa mempunyai kedudukan penting, tidak hanya dalam urusan agama tetapi meyangkut kehidupan berbangsa dan bernegara serta berkehidupan sebagai salah satu sumber rujukan yang bersifat logis maupun yuridis secara eksplisit dalam menata kehidupan yang layak dan semestinya. Sebagai salah satu referensi atau rujukan dalam mengatasi problematika, namun kedudukan fatwa pada masing-masing negara bebeda-beda sehingga berdampak pula terhadap kualitas fatwa yang diproduksi.
\end{abstract}

Kata Kunci: Kedudukan; Fatwa; Negara Muslim 


\section{PENDAHULUAN}

Sebagai umat Islam harus berpegang teguh pada sumber utama ajaran Islam yang dibawa oleh Nabi Muhammad yakni Al-Quran dan Al-Hadits. Sebab keduanyalah sumber dasar yang mengatur segala lini kehidupan manusia, khusunya ummat muslim dalam menjalankan roda kehidupannya yang berdasarkan nilai-nilai yang dikehendaki oleh Tuhan. Apabila terjadi permasalahn dalam kehidupan, maka sumber rujukan utama dalam mencari jawaban sebagai solusi atas permasalahn tersebut adalah kalam Ilahi dan hadis Nabi.

Ketika Nabi Muhammad masih hayat segala permasalahan yang ada disandarkan langsung kepadanya, sehingga semua jawaban atas segala problem masa itu dapat dijadikan sebagai fatwa yang disebut dengan dengan hadis. Dengan itu dapat dikatakan bahwa fenomena dalam realita permintaan fatwa sudah ada sejak zaman Nabi seperti yang diabadikan dalam al-Qur'an surat an-Nisa ayat $127 .{ }^{1}$

Namun ketika Nabi telah wafat, seketika itu juga salah satu sumber utama ajaran Islam teputus, padahal problem kehidupan manusia semakin hari semakin berubah, yang justru sangat membutuhkan tanggapan logis ataupun yuridis secara eksplisit. Untuk itu para sahabat Nabi, lanjut ke tabi'in, dan sampai kepada ulama saat ini sebagai penyambung lidah Nabi berkewajiban untuk melanjutkan tradisi pemberian fatwa pada ummat, sebab mereka para ulama sudah mendapatkan pengakuan yang khusus sebagai pewaris perjuangan kenabian. Maka atas dasar itulah mereka harus menyusun strategi untuk menangani segala permasalahan ummat dengan melanjutkan tradisi fatwa yang sudah dicontohkan oleh Nabi sebelumnya.

Mengenai ulama yang pantas mengeluarkan fatwa menurut Imam bin Hambal harus ada pada dirinya 5 hal yakni: Berilmu, yang didasari oleh intelegensi yang berkualitas khusunya dalam ilmu agama Islam; Memiliki kecerdikan dalam menangani sebuah kasus agar tidak mudah terjebak dan tertipu; Mempunyai ketenangan dan kewibawaan agar fatwa yang dikeluarkan jelas utuh dan benar; Ikhlas karena Allah tanpa ada maksud lain yang berbau keduniaan; Mempunyai kehidupan yang terjamin sehingga tidak menggantungkan kehidupannya pada orang lain, hal ini perlu untuk menjaga independensi atas fatwa yang

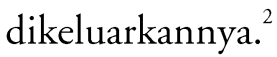

Di setiap negara, ada ulama-ulamak yang khusus diberi wewenang dalam mengurusi fatwa tersebut, bahkan ia memiliki lembaga khusus yang dijadikan sebagai pusat kelembagaan dan pengkajian dalam menangani semua kasus yang diajukan oleh penduduk

\footnotetext{
${ }^{1}$ Yusuf Qardawi, Al-Ijtihad, Fi Al-Isyarah Al-Islamiyah Ma'a Nadzariyyat Tahliliyyah Fi Al-Ijtihad Al-Mu'ashir, cet 1, (Kuwait : Dar al-Qalam, 1996), 115.

${ }^{2}$ Ma'ruf Amin, Fatwa dalam Sistem Hukum Islam, (Jakarta : Paramuda Advertising, 2008), 24.
} 
suatu negara dalam rangka mencari solusi atau jawaban yang pasti terhadap permasalahan yang mereka hadapi.

Fatwa yang dikeluarkan oleh lembaga fatwa di masing-masing negara memiliki sifat yang berbeda-beda, ada yang bersifat mengikat dan ada juga yang bersifat tidak mengikat. Misalnya fatwa yang bersifat mengikat biasanya adalah fatwa yang dikeluarkan oleh lembaga fatwa yang berada dalam struktur pemerintahan, atau dengan kata lain negara menempatkan fatwa sebagai sistem hukum di negaranya. Sebut saja misalnya Negara Berunai yang memposisikan lembaga fatwa pada sistem pemerintahannya, sehingga produk yang dihasilkan oleh lembaga fatwa tersebut telah terkontaminasi atas kepentingan pemerintah yang berkuasa.

Sedangkan bagi negara yang tidak menjadikan fatwa bagian dari struktur pemerintahannya atau dengan kata lain menjadikan fatwa berada di luar sistem hukumnya, maka biasanya hasil fatwa yang dikeluarkan sifatnya tidak mengikat sehingga boleh dilaksanakan dan boleh juga tidak. Biasanya lembaga fatwa semacam ini dapat dikatakan kualitas fatwa yang dihasilkan murni dari semua kepentingan pemerintah alias indevenden. Sebut saja misalnya negara Indonesia yang mempunyai lembaga fatwa yang disebut MUI (Majelis Ulama Indonesia), sebuah lembaga fatwa yang berada di luar sistem hukum dan struktur pemerintahan. Produk fatwa yang dikeluarkan MUI sama sekali tidak mengikat seperti larangan merokok, namun dalam beberapa fatwa yang dikeluarkan oleh MUI digunakan juga sebagai rujukan oleh pemerintah sebagai produk hukum yang dipedomani, misalnya seperti operasional ekonomi syariah.

Oleh sebab itu dapat dipahami bahwa lembaga fatwa yang berada dalam sistem hukum atau struktur pemerintahan memiliki kekuatan hukum yang kuat dan mendapat kedudukan yang tinggi, sehingga poroduk fatwa itu akan bersifat mengikat. Beda halnya dengan lembaga fatwa yang berada di luar sistem hukum dan struktur pemerintahan yang bersifat subjektif dan tidak mengikat, sehingga boleh ditaati dan boleh juga tidak.

Muhammad Muzakkar menerangkan bahwa sifat dasar fatwa itu pada hakikatnya adalah kasuistik yakni suatu respon yang lahir dari sebuah kasus yang dipertanyakan dalam upaya mendapatkan jawaban atas yang dialaminya. Maka atas dasar itu, fatwa yang dikeluarkan oleh lemabaga fatwa kepada si peminta fatwa hukumnya tidak mengikat, dalam arti peminta tidak harus mengikuti isi dari fatwa yang diberikan. Hal itu menandakan bahwa fatwa cenderung bersifat dinamis, responsif, dan elastis sehingga kapanpun fatwa tersebut bisa berubah-ubah sesuai dengan keadaan niat, kebiasaan, waktu dan tempat. 
Maka dalam makalah ini, penulis akan membahas tetang kedudukan fatwa di negaranegara Islam yang difokuskan hanya pada 3 Negara saja yakni Indonesia, Berunai Darussalam, dan Mesir.

\section{METODE}

Penelitian ini adalah penelitian kepustakaan (Library Research) yaitu penelitian dengan memakai leiteratur-literatur yang berhubungan dengan kedudukan fatwa di negara muslim. ${ }^{3}$ Sumber data dalam penelitian ini ada dua, yaitu sumber data primer yang berkaitan langsung dengan kedudukan fatwa di Indonesia, Berunai Darussalam, Malaysia, dan Mesir. Adapun data skundernya adalah buku-buku lain berupa tulisan para ahli yang secara langsung maupun tidak langsung membahas masalah yang penulis kaji.

Sifat penelitian ini adalah deskriptif-komparatif, yang berusaha menggambarkan dengan jelas dan sistematis masalah penelitian, dilakukan analisis dan dikomparasikan secara bersama setiap pembahasan, ${ }^{4}$ yaitu kedudukan fatwa di Indonesia, Berunai Darussalam, Malaysia, dan Mesir. Data yang terkumpul dan telah tersusun tersebut dianalisis dan dikomparasikan sehingga akan dapat menjawab permasalahan yang diangkat. Sementara pendekatan yang dipakai dalam penelitian ini adalah pendekatan normatif.

\section{PEMBAHASAN}

\section{Kedudukan Fatwa di Indonesia}

Fatwa bisa dikeluarkan oleh orang pribadi maupun sekelompok orang seperti organisasi atau lembaga keislamanan lainnya, seperti halnya di Indonesia ada lembaga khusus yang berfungsi mengeluarkan fatwa yang berada dalam suatu lembaga yang disebut MUI (Majelis Ulama Indonesia). MUI adalah organisasi yang ada dalam masyarakat dan tidak termasuk dalam institusi negara atau representasi Negara Kesatuan Republik Indonesia, sehingga fatwa yang dikeluarkan oleh MUI tidak mempunyai kekuatan hukum untuk dipaksakan bagi seluruh rakyat Indonesia. Penduduk Indonseisa mempunyai agama berbeda-beda, sedangkan MUI merupakan organisasi sebuah komunitas umat tertentu yakni Islam, yang secara otomatis kekuatan hukum yang dikeluarkannya hanya kepada komunitas umat Islam yang merasa mempunyai keperluan terhadap MUI itu sendiri.

Fungsi dari lembaga MUI adalah sebagai sarana untuk pemberdayaan umat Islam atas segala permasalahan yang dirasakan dan dialami, yang membutuhkan solusi dari orang yang dituakan yakni alim ulama yang ada dalam suatu organisasi atau suatu lembaga.

\footnotetext{
${ }^{3}$ J.N.D. Anderson, Hukum Islam di Dunia Muslim, terj. Machnun Husein, cet. I (Surabaya: CV. Amapress, 1991), h. 90-91.

${ }^{4}$ Hilman Hadikusuma, Metode Pembuatan Kertas Kerja Ilmu Hukum (Bandung: Mandar Manju, 1995), h. 10.
} 
Lembaga tersebut merupakan denyut jantung kehidupan sosial kultural masyarakat, sehingga semua aksinya dapat tergambarkan secara mendalam pada proses penyelesaian permasalahan yang dialami oleh masyarakat itu sendiri.

Lembaga MUI terdiri dari kumpulan para alim ulama yang mengabdikan diri sebagai refesentasi hukum agama, sehingga mempunyai peran fungsi sebagai berikut: Sebagai pewaris tugas-tugas kenabian, sebagai penegak amar ma'ruf nahi mungkar, sebagai pembimbing dan pelayan umat, sebagai gerakan Islam wa al-tajdid, dan sebagai Mufti atau pemberi fatwa.

MUI dalam mengeluarkan sebuah fatwa tidak lepas dari sumber hukum Islam yang utama yakni al-Qur'an al-Hadits, kemudian ditambah dengan hasil pikiran Ra'yu yang berdasarkan pada pengalaman dan pengetahuan dengan berdasarkan pada metode sebagai beikut: Ijma’ yakni persetujuan para ahli mengenai masalah yang dibahas; Qiyas yakni dengan meyamakan hukum permasalahan yang dibahas sesuai dengan ketetntuan yag ada dalam al-Qur'an dan sunnah Nabi; Istidal yakni menarik kesimpulan dari dua hal yang berbeda untuk disatukan, misalnya nilai agama dan nilai adat istiadat; Al-Maslih Al Mursalah yakni menarik pertimbangan hukum tantang kemaslahatan yang lebih besar untuk kepentingan umum; Istihsan yakni menentukan hukum yang berbeda dari ketentuan yang sudah ada demi keadilan sosial; Istishab yakni menetapkan hukum sesuatu hal menurut keadaan yang terjadi sebelumnya, sampai ada dalil yang mengubahnya; Urf yakni menyesuaikan dengan adat istiadat yang tidak berlawanan dengan hukum Islam. ${ }^{5}$

Jadi produk fatwa yang dihasilkan MUI berdasarkan pada hasil ijtihad dan pergumulan pemikirian para alim ulama dengan melalui proses ijma' yakni ketetapan suatu hukum yang disetujui bersama para ahli tentang suatu masalah yang dibahas atau suatu masalah yang diajukan oleh orang pada suatu waktu dan tempat.

Namun perlu diketahui bahwa Produk yang dikeluarkan MUI hukumnya tidak mengikat, karena lembaga tersebut tidak termasuk dalam struktur pemerintahan dan hukum negara, sehingga fatwa yang dikeluarkan boleh diikuti dan boleh juga tidak. Hal itu berdasarkan pada Undang-Undang Nomor 12 Tahun 2011 dalam pasal 7 ayat 1 angka 2 disebutkan bahwa hirarki peraturan perundang-undangan terdiri dari: Undang-uandang Dasar Negara Republik Indonesia Tahun 1945, Ketetapan MPR (Majelis Permusyawaratan Rakyat), Undang-Undang/Peraturan Pemerintah Pengganti Undang-Undang, Peraturan pemerintah, Peraturan Presiden, Peraturan Daerah Propinsi, dan Peraturan Daerah Kabupaten/ Kota. Jenis Peraturan Perundang-undangan selain yang disebutkan di atas, mencakup peraturan yang ditetapkan oleh MPR (Majelis Permusyawaratan Rakyat), DPR (Dewan Perwakilan Rakyat), DPD (Dewan Perwakilan Daerah), MA (Mahkamah Agung),

\footnotetext{
${ }^{5}$ Mohammad Daud Ali, Hukum Islam: Pengantar Ilmu Hukum dan Tata hukum Islam di Indonesia Edisi Keenam, (Jakarta : 1998), 71-111.
} 
MK (Mahkamah Konstitusi), Komisi Yudisial, Bank Indonesia, Menteri Badan, Lembaga, atau komisi yang setingkat yang dibentuk dengan Undang-Undang atau Pemerintah atas perintah Undang-Undang, DPRD (Dewan Perwakilan Rakyat Daerah Provinsi), Gubernur, Dewan DPRD (Dewan Perwakilan Rakyat Daerah Kabupaten/Kota, Bupati/Walikota, Kepala Desa atau yang setingkat. ${ }^{6}$

Berdasarkan itu maka secara jelas bahwa fatwa MUI bukanlah termasuk lemabaga hukum di Indonesia sampai fatwa tersebut diserap oleh pemerintah untuk dijadikan sebagai peraturan perundang-undangan. Sebagaimana yang dibuktikan dalam masalah ekonomi syariah yang merupakan produk asli yang dihasilkan oleh MUI, kemudian diambil oleh pemerintah sehingga fatwa tersebut hukumnya mengikat bagi pelaku usaha syariah, sebagaimana yang tercantum dalam fatwa DSN (Dewan Syariah Nasional)-MUI. Hal itu juga sesuai dengan penjelasan Yeni Salma dalam sebuah penelitian yang dilakukannya bahwa ekonomi syariah adalah salah satu pruduk fatwa mempunyai kekuatan hukum legal yang dijadikan hukum positif yang bersifat mengikat.

Jika merujuk pada kasus tersebut, maka menunjukkan fatwa yang diproduksi MUI tidaklah sia-sia. Menurut Mahfud. MD, fatwa MUI tidak jarang digunakan juga sebagai keterangan atau pendapat ahli di dalam persidangan dalam rangka pembuktian kasus konkret individual, bukan sebagai peraturan yang bersifat abstrak-umum. Seperti contoh kasus Ahok, dimana pihak kepolisian meminta fatwa kepada MUI tentang ucapan Ahok di pulau seribu tentang surat al-Maidah yang menyatakan: Jangan mau dibohongi pake surat al-maidah". Setelah mengkaji seluruh yang berkaitan tentang ucapan tersebut, maka keluarlah fatwa MUI yang menyatakan hal itu termasuk penistaan agama. Atas dasar fatwa itu, maka pihak kepolisian dan pengadilan menghukumi Ahok sebagai terdakwa dan dijembloskan ke dalam penjara.

Namun demikian menurut Mahfud bila dilihat dari sudut konstitusi dan hukum, fatwa MUI tidak dapat dipaksakan melalui pihak penegak hukum. Bisa saja fatwa itu berfungsi untuk menyadarkan masyarakat tentang agamanya secara pribadi, namun tidak dapat menjadi hukum yang tetap dalam negara, karena sifatnya yang tidak lebih dari pendapat sehingga pihak yang meminta fatwa boleh diikuti dan boleh juga tidak.

Sepadan dengan itu Ainun Najib dalam keterangannya menyebutkan, walaupun MUI bukan institusi miliki negara yang mempresentasikan negara, namun ia termasuk elemen infrasrtrukur ketatanegaraan yang memainkan peranan penting dalam membimbing ummat Islam yang mayoritas di negara ini, sebagai wadah untuk 
mengumpulkan aspirasi ummat Islam yang berkaitan dengan permasalahan kehidupan yang diselaraskan dengan nilai hukum ajaran Islam yang sesungguhnya. ${ }^{7}$

MUI dalam infrastuktur berada pada kelompok kepentingan institusional yakni perkumpulan ulama' yang mengadakan penyatuan atas suatu kepentingan tertentu menyangkut urusan suatu kelompok, institusi, atau masyarakat secara umum. Berdasarkan itu maka MUI termasuk pada spesifikasi interest group instittusional yang terdiri dari semua profesi dan aliran pemikiran atau konsentrasi yang berbeda dengan tujuan untuk mencari suatu jawaban atas permasalahan yang dibahas.

\section{Kedudukan Fatwa di Berunai Darussalam}

Brunei Darussalam merupakan salah satu negara Melayu yang menjadikan Islam sebagai agama resmi, sebab itu maka semua perundang-undangannya merujuk pada nilai hukum ajaran Islam yang berdampak pula pada semua kehidupan sosial, ekonomi, dan politiknya.

Sejak Negara Brunei Darussalam lahir ia sudah dipimpin oleh para raja-raja yang beragama Islam bermadzhab Syafi'i, ${ }^{8}$ sehingga hal itu menjadi penyebab utama yang melandaskan Negara Brunei menjadi negara Islam. ${ }^{9}$ Awang Alak Betatar merupakan Sultan Brunei pertama yang dikenal dengan sebutan Sultan Muhammad Syah pada tahun 1363 Masehi sampai 1402 Masehi. Walaupun Negara Brunei di pimpin oleh orang Islam, namun membolehkan adanya agama-agama lain atau kepercayaan lain yang dianut oleh peduduknya, bahkan semua amalan dan kegiatan ibadah penduduknya yang menganut kepercayaan lain mendapatkan perhatian yang sama dengan penduduk yang mayoritas muslim.

Dalam tradisi kesultanan Berunai Darussalam didasarkan pada empat unsur yakni: Kanun merujuk pada kanun Berunai atau perundang-undangan Berunai, Syarak merujuk pada ajaran-ajaran agama Islam, adat istiadat merujuk pada adat kebiasaan setempat, dan Resan merujuk pada hal-hal di luar adat istiadat.

${ }^{7}$ Ainun Najib. Fatwa Majelis Ulama Indonesia Dalam Perspektif Pembangunan Hukum Responsif, (Jurnal: Volume 4, No. 2, Desember 2012). 375-375.

${ }^{8}$ Sebagaiman yang diatur dalam konstitusi Negara Brunei Bahagian II Ugama dan Adat Istiadat Pasal 3 (1) menyebutkan bahwa Ugama resmi bagi Negara Brunei Darussalam adalah Ugama Islam. Lebih khusus disebutkan pada bahagian I Permulaan pada bagian Tafsiran 2 (1) bahwa "Ugama Islam" bermakna Ugama Islam menurut Ahlis Sunnah Waljamaah mengikut Mazhab Shafi'ee.

${ }^{9}$ Haji Japar bin Haji Mat Dain, Institusi Fatwa: Peranan dan Sumbangan Jabatan Mufti Kerajaan Negara Brunei Darussalam, Disertasi Dihadapkan Untuk Ijazah Sarjana Syariah Akademi Pengajian Islam Universiti Malaya Kuala Lumpur, (Kuala Lumpur : Bahagian Pengajian Syariah Akademi Pengajian Islam Universiti Malaya Kuala Lumpur Malaysia, 1999), 100. 
Sebelum negara Berunai Darusslam mempunyai institusi fatwa hukum Islam, penyelesaian suatu permasalahan yang dialami oleh masyarakat muslim ditangani langsung oleh setiap individu ulama setempat, guru atau imam masjid yang dimuliakan. Akan tetapi setelah diresmikan institusi fatwa pada tahun 1962, ulama memainkan peran yang cukup signifikan dalam menangani hal ehwal hukum-hukum syara' dalam rangka mensejahterakan rakyat dan negara Brunei Darussalam secara umum. Hal tersebut merupakan keputusan yang dikeluarkan oleh Sultan Haji Omar Ali Saefudin Sa'adatul Khairi waddin sultan yang di-pertuan negara Brunei Darussalam yang ke-28. ${ }^{10}$

PeRubahan tersebut diselaraskan dengan Undang-Undang Nomor 20 Tahun 1955 Negara Brunei Darussalam yang digelar Undang-Undang Ugama Adat Istiadat Negeri dan Mahkamah Kadi 1955 yang kini bernama akta Majlis Ugama Islam dan Mahkamah Kadi penggal 77 (Akta MUI 1984 ) setelah di semak semula pada tahun 1984."

Pada peringkat awal penumuhan, ia diletakkan di dalam sebahagian dari Jabatan Hal Ehwal Ugama (JHEU) yang diberi tanggung jawab dalam hal-hal mengurusi yang mengenai fatwa tapisan khutbah, televisi, perpustakaan, film penerbitan, serta jawatan kuasa undang-undang dan jawatan kuasa kehakiman bagi Majlis ugama Islam Brunei. Kemudian pada tahun 1986 JHEU dimasukkan menjadi satu bagian dalam jabatan KHEU (Kementrian Hugama Ehwal Ugama) yang bercampur dengan jabatan lainnya seperti Jabatan Pentadbiran, Jabatan Hal Ehwal Syariah, Jabatan Pengajian Islam, Jabatan Urusan Haji dan Perhubungan Muslim dan Pusat Da'wah Islamiyah. Fatwa diletakkan di bawah Jabatan Hal Ehwal Syariah. ${ }^{12}$ khusus yang mengurusi fatwa dibahagikan kepada tiga cawangan yaitu penyediaan dan penyebaran fatwa, rujukan dan penapisan, dan perkhidmatan. $^{13}$

Kemudian pada 7 November tahun 1994 di bawah pemerintahan yang mulia Paduka seri Baginda Sultan Haji Hassanal Bolkiah yang di-pertuan Negara Brunei Darussalam memberikan kepercayaan kepada institusi fatwa untuk lebih leluasa dalam pergerakannya, untuk itu diberikan tugas tersendiri sebagai organisasi tersendiri di bawah jabatan Perdana Menteri bernama JMK (Jabatan Mufti Kerajaan). Mufti kerajaan tersebut bertanggung jawab langsung kepada ke bawah duli Yang Maha mulia yang berkaitan dengan tugas-tugas sebagai Mufti kerajaan. Sejak dipisahkan Departemen Mufti kerajaan, semakin

\footnotetext{
${ }^{10}$ Haji Muhammad Hadi Abdullah, Dalam Al-Hadaf Tahun 1 Bilangan 1, Jabatan Mufti Kerajaan, (Bandar Seri Begawan, 1997), pp. 13.

${ }^{11}$ Pehin Jawatan Luar Pekerma Raja Dato Seri Utama Dr. Ustaz Haji Awang Mohd Zain Bin Haji Serudin, Brunei Sebuah Negara Islam: Latar Belakang Keislamannya, (Akademi Pengajian Brunei Universiti Brunei Darussalam ; Bandar Seri Begawan, 1996).

${ }^{12}$ Haji Japar bin Haji Mat Dain, Institusi Fatwa: Peranan dan Sumbangan Jabatan Mufti Kerajaan Negara Brunei Darussalam, 100, mengutip Buku Kementerian Hal Ehwal Ugama Brunei, terbitan Pusat Dakwah Islamiah, 12.

${ }^{13}$ Abdul Qayyuum Aminnuddin \& Mohd Anuar Ramli, Peranan Institusi Fatwa Negara Brunei Darussalam Dalam Menangani Isu-Isu Kepenggunaan Halal, (Conference Paper· September 2015), 6.
} 
mengukuhkan posisi dan status fatwanya menjadi semakin kuat dalam mengeluarkan Irsyad dan fatwa serta mengeluarkan dan menyebarkan ilmu pengetahuan Islam.

Kemudian pada tahun 2005 atas perintah sultan yang di-pertuan negara Brunei Darussalam, MKB di isytiharkan sebagai jawatan bertaraf menteri sempena titah Khas KDYMM (Kebawah Duli Yang Maha Mulia) mengenai rombakan keahlian majelis Meusyuarat Menteri-Menteri Kabinet. ${ }^{14}$

Karena mufti yang bertugas mengeluarkan fatwa tersebut bagian dari pemerintahan Brunei Darussalam, maka dari segi legalitas fatwa sangat ketat dan wajib diikuti oleh penduduk muslim di Berunai. Kemudian pada sisi lain semua bentuk yang berkaitan dengan mufti ada pada tangan kesultanan, sehingga mufti kerajaan bisa saja diberhentikan kapan saja oleh sultan sebagaimana yang diatur dalam Undang-undang Negara Brunei Darussalam Pasal 40 (1) Penggal 77 menyebutkan bahwa: Ke bawah Duli Yang Maha Mulia boleh dengan pemberitahuan yang ditunjukkan dalam Warta Kerajaan melantik sesiapa saja yang sesuai untuk menjadi Mufti Kerjaan Negara Brunei Darussalam dan boleh pada bila-bila masa membatalkan nama-nama lantikan tersebut. Dengan syarat bahwa dalam hal mana-mana kekosongan dalam lantikan Mufti kuasa-kuasa dan tugas-tugas yang diberikan ke atas Mufti oleh Akta ini hendaklah dijalankan oleh Penasihat Ugama”.

Bila ditinjau dari Mekanisme dalam pengambilan keputusan fatwa, yang pertama kali yang harus diperhatikan oleh mufti adalah melihat siapa yang meminta fatwa, kemudian menelusuri sejauh mana kesungguhan orang yang meminta fatwa, sebab jika orang yang meminta fatwa tidak sungguh-sungguh maka tidak patut untuk dijawab. Kemudian sebelum mengeluarkan fatwa, perlu juga kiranya para ahli-ahli yang hadir dalam pembahasan permasalahan tersebut untuk menyatukan persepsi atau pendapat. Apabila ada suatu pertentangan di dalam diskusi tersebut maka fatwa yang diambil adalah menurut suara terbanyak.

Adapun metode yang digunakan dalam mengeluarkan fatwa sudah tertuang di dalam undang-undang 77 yang menyebutkan hendaknya fatwa yang dikeluarkan harus berlandaskan Mazhab Syafi'i, namun apabila ada suatu permasalahan yang membutuhkan perbandingan mazhab, maka boleh melihat 3 madzhab yang lain seperti Hanafi, Maliki, Hambali atas izin dari Sultan dan disertai dengan penjelasan yang dianggap perlu. ${ }^{15}$

\footnotetext{
${ }^{14}$ Abdul Qayyuum Aminnuddin \& Mohd Anuar Ramli, Peranan Institusi Fatwa Negara Brunei Darussalam Dalam Menangani Isu-Isu Kepenggunaan Halal, (Conference Paper· September 2015), 6.

${ }^{15}$ Isa Ansori, Analisis Kedudukan Fatwa Di Beberapa Negara Muslim: (Malaysia, Brunei Darussalam dan Mesir), Volume 3, Nomor 1, Juni 2017, 153.
} 


\section{Kedudukan Fatwa di Malaysia}

Malaysia adalah negara federasi yang berlandaskan agama Islam, namun tetap memberi peluang bagi agama lain untuk dipraktekkan secara aman dan damai di seluruh bagian negara Federasi. Yang di Pertuan Agong mengepalai agama Islam di wilayah negara Federasi Kuala Lumpur, Labuan dan Putrajaya; dan untuk tujuan ini Parlemen diizinkan oleh hukum untuk membuat ketentuan dalam rangka mengatur urusan agama Islam dan merupakan sebuah Dewan yang menasehati Yang di Pertuan Agong terkait dengan agama Islam.

Sementara itu konstitusi negara bagian Malaka, Penang, Sabah dan Serawak, masingmasing akan membuat peraturan untuk dirundingkan bahwa Yang di Pertuan Agong mengepalai agama Islam di negeri-negeri itu. Berdasarkan konstitusi federal artikel 11 (4) hukum negara federal dapat mengontrol atau membatasi penyebaran doktrin agama atau kepercayaan manapun di antara orang yang beragama Islam berkenaan dengan wilayah federal Kuala Lumpur, Labuan dan Putrajaya. Konstitusi artikel 12 (2) juga menjamin bahwa setiap kelompok agama mempunyai hak menciptakan dan memelihara institusi untuk pendidikan anak menurut agamanya, dan tidak boleh ada diskriminasi hukum terhadap institusi dan peraturan administratif, tetapi harus sah bagi federasi atau negara bagian membuat atau memelihara atau membantu pembentukan atau pemeliharaan institusiinstitusi Islam atau menyediakan atau membantu menyediakan petunjuk agama Islam dan menyediakan biaya yang diperlukan untuk tujuan itu. Berdasarkan ketentuan konstitusi ini, baik federasi maupun negara bagian mempunyai tanggung jawab sama dalam mengembangkan segala sesuatu berkaitan dengan pengembangan keagamaan Islam termasuk fatwa di negara Malaysia.

Manajemen fatwa di negara-negara bagian diberlakukan melalui undang-undang negara yang dinamakan dengan Undang-undang Pentadbiran (Administrasi) Agama Islam. Melalui pemberlakuan ketentuan undang-undang ini, kerajaan negara bagian mendirikan departemen Mufti. Departemen ini diwujudkan secara terpisah dari MAIN (Majlis Agama Islam Negeri), tetapi Mufti bertanggung jawab langsung dalam membantu dan memberikan nasihat kepada DYMM (Duli Yang Maha Mulia) Sultan atau Yang di Pertuan Agong yang berhubungan dengan semua hukum syara' dan Mufti juga menjadi penguasa utama setelah DYMM Sultan atau Yang di-Pertuan Agong. ${ }^{16}$

Mufti merupakan pihak berkuasa utama setelah Sultan dalam urusan agama bagi setiap negara bagian untuk urusan yang berkaitan dengan agama. Meskipun demikian Mufti tidak boleh campur tangan dalam administrasi hukum syara' di Mahkamah Syariah. Mahkamah Syariah adalah badan tersendiri dalam penegakan keadilan yang independen.

\footnotetext{
${ }^{16}$ Mohd. Mohadis Yasin, "Pengurusan dan Penyelarasan Fatwa: Pelaksanaan dan Cabaran di Malaysia" (Jurnal Pengurusan dan Penyeledikan Fatwa (JFMR), Vol. 1, 2007), 122.
} 
Sebelum amandemen undang-undang negara dibuat, Mufti merupakan ketua komite Mahkamah Ulang Bicara (Mahkamah Banding) untuk mayoritas negara bagian.

Secara umum Mufti di Malaysia memiliki tugas-tugas sebagai berikut: a) Penasihat ehwal Islam agama Islam kepada Kerajaan negeri; b) Ahli Majlis (Anggota Dewan) Agama Islam Negeri; c) Pengerusi Jawatan kuasa (Ketua Komite) Fatwa/Syariah Negeri; d) Ahli Jawatan kuasa (Anggota Komite) Fatwa Peringkat Kebangsaan (Anggota Komite Fatwa Tingkat Nasional); e) Pengerusi Jawatan kuasa (Ketua Komite) Pemilihan Imam-Imam Masjid/Surai; f) Menyelesaikan atau menjawab permasalahan berkaitan agama Islam; g) Menyemak teks khutbah Jumaat/hari raya; h) Mengesahkan Taqwim Islam di peringkat negeri; i) Memberi ceramah dan syarahan di masjid-masjid, surau dan lain-lain; j) Membaca doa di majlis-majlis rasmi kerajaan. ${ }^{17}$

Dalam menjalankan tugas-tugas dan tanggung jawab di atas, Mufti dibantu oleh pegawai dan pembantu pegawai urusan Islam serta beberapa orang staf pendukung. Dalam urusan mengeluarkan suatu fatwa, Mufti tidak boleh bertindak secara proaktif atau berdasarkan permintaan pihak manapun. Bagaimanapun fatwa terkait hendaklah dibuat melalui komite Syariah yang dipanggil bersidang untuk tujuan tersebut oleh Mufti. Suatu kenyataan yang dibuat oleh Mufti tidak boleh dianggap sebagai fatwa kecuali ia telah diwartakan.

Mufti diberi wewenang mengubah, atau membatalkan fatwa apapun yang lebih dahulu dikeluarkan olehnya atau Mufti terdahulu. Setiap fatwa apabila telah diwartakan akan mengikat setiap orang di negara berkenaan serta mengikat semua Mahkamah Syariah di negeri berkenaan.

\section{Administrasi Fatwa Tingkat Negara Bagian}

Mufti-mufti di Malaysia mengeluarkan fatwa melalui Komite Fatwa Negara Bagian atau Komite Syariah Negara Bagian atau Wilayah Persekutuan berdasarkan tata cara dan wewenang yang diberikan melalui Akta/Enakmen Undang-Undang Pentadbiran Agama Islam Wilayah Persekutuan atau negeri masing-masing. Dikarenakan setiap negeri mempunyai perbedaan keanggotaan dan cara pengangkatan anggota-anggota Jawatankuasa Syariah Negeri (Komisi Syariah Negara Bagian), Jabatan Kemajuan Islam Malaysia (JAKIM) melalui Jawatan kuasa Teknikal Undang-Undang Syarak dan Sipil berusaha mengadakan penyeragaman keanggotaan dan pengangkatan anggota Komite Syariah setiap negara bagian sebagai berikut: a) Mufti sebagai Ketua; b) Wakil Mufti; c) Dua orang anggota Majlis yang dinamakan oleh Majlis; c) tidak kurang dari dua orang dan tidak lebih dari tujuh orang yang layak dan sesuai yang dilantik oleh Majlis; d) seorang pegawai dari Jabatan Mufti yang dilantik oleh Majlis sebagai Sekretaris.

\footnotetext{
${ }^{17}$ Abdul Hamid Yusoff bin Yunus (1991) "Ijtihad dan Amalannya dalam Pembinaan Fatwa di Malaysia”, (Latihan Ilmiah Sarjana Pengajian Islam, Akademi Pengajian Islam, Universiti Malaya), 143 -252
} 
Komite Fatwa Negara Bagian bertanggung jawab menyediakan fatwa untuk negeri masing-masing atas perintah DYMM Sultan atau Yang di-Pertuan Agong atau atas kehendak Komite sendiri atau permintaan masyarakat Islam yang dibuat melalui surat dan dialamatkan kepada Mufti mengenai persoalan apapun yang belum muktamad atau menimbulkan kontroversi berkaitan dengan hukum syarak. Untuk mewujudkan prosedur mengeluarkan fatwa yang seragam di setiap negeri, satu tata cara pembuatan fatwa telah ditetapkan. Tata cara pembuatan atau pengeluaran fatwa oleh Komite Fatwa Negara Bagian adalah melalui proses berikut: a) Kajian dan Penyelidikan; b) Musyawarah Komite Fatwa Negeri; c) Mengajukan keputusan fatwa kepada MAIN; d) Mendapatkan persetujuan DYMM Sultan atau YDPA bagi pewartaan fatwa; e) Menyiarkan dalam warta. $^{18}$

Setiap fatwa yang telah diputuskan oleh Komite Fatwa Negara Bagian dan telah diwartakan dan disyahkan akan mengikat tiap-tiap orang Islam yang berada di negeri bersangkutan. Komite Fatwa Negara Bagian juga berhak mengkaji fatwa yang telah dikeluarkan oleh Komisi Fatwa Nasional sebelum diwartakan dan diterapkan di negaranegara bagian. Ini karena yang memiliki berwenang mengenai agama Islam ada pada pihak berwenang agama Islam di tiap-tiap negara bagian. Namun demikian, pemberlakuan Undang-Undang Administrasi Agama Islam Negara Bagian disarankan dengan rekomendasi Komite Fatwa Nasional, fatwa yang diputuskan pada tingkat nasional harus diwartakan tanpa perubahan atau modifikasi apapun.

Fatwa yang dikeluarkan oleh Komite Fatwa Nasional atau Komite Fatwa Negara Bagian adalah merujuk kepada pandangan Imam Shafie kecuali pandangan itu tidak sesuai dengan maslahah umat Islam. Dalam keadaan ini fatwa akan merujuk kepada pandangan mazhab ahli Sunnah lain yaitu Hanafi, Maliki atau Hambali. Apabila komite fatwa berpendapat tidak ada satupun qaul muktamad dari ke empat mazhab tersebut yang dapat diikuti tanpa membawa kepada keadaan yang bertentangan dengan kepentingan umum, maka komite fatwa dapat membuat fatwa tanpa terikat dengan mazhab empat manapun. Ketentuan ini dibuat supaya tidak menimbulkan kekeliruan antara fatwa dengan pandangan pribadi individu tertentu menyangkut suatu masalah.

Untuk menghindari kekhawatiran terhadap dampak negatif fatwa yang diamalkan, terutama menyangkut permasalahan pada saat itu atau permasalahan baru yang memerlukan banyak disiplin ilmu dan kepakaran tertentu, lazimnya komite fatwa akan akan bekerja sama dengan pihak tertentu mengadakan kajian dan penelitian sebelum fatwa diputuskan, ini bertujuan agar hukum yang difatwakan lebih mantap dan padu.

$$
\text { hingga (9). }
$$

${ }^{18}$ Rang Undang-Undang Pentadbiran Agama Islam Negeri (Wilayah-Wilayah Persekutuan), Pasal 36 (1) 
Fatwa yang telah diwartakan, setiap orang Islam diharapkan mematuhi dan berpegang dengan fatwa tersebut dan mahkamah seharunya juga mensosialisasikan fatwa agar dapat ditaati terkait perkara yang diatur. Siapa saja yang menyampaikan, mengembangkan, dan menyebarkan pendapat apapun tentang ajaran Islam, hukum syara' atau apa saja yang bertentangan dengan fatwa yang telah disyahkan adalah melakukan kesalahan melawan Akta atau Enakmen Kesalahan Jenayah Syariah NegeriNegeri. Hanya Komite Fatwa Negeri yang diberi kewenangan untuk mengubah atau membatalkan fatwa yang telah disiarkan dalam warta.

\section{Hubungan antara Komite Fatwa Nasional dan Komite}

Fatwa Negara Bagian untuk tujuan mengkoordinasikan fatwa di seluruh negara, Majlis Kebangsaan Bagi Hal Ehwal Islam Malaysia (MKI) telah membentuk Jawatan kuasa Fatwa Kebangsaan (Komite Fatwa Nasional). Komite ini diberi tanggung jawab dalam menimbang, memutus dan mengeluarkan fatwa apapun yang berkaitan dengan agama Islam yang Majlis Raja-Raja merujuk kepadanya. Jabatan Kemajuan Islam Malaysia (JAKIM) selaku sekretariat Komite Fatwa diberi tanggung jawab membantu dan melaksanakan segala keputusan komite tersebut.

Meskipun Komite Fatwa Nasional telah dibentuk, beberapa kelemahan terkait penyelarasan fatwa masih ditemui. Kelemahan yang teridentifikasi adalah terkait penegakan keputusan-keputusan fatwa nasional di tingkat negara bagian, penyelarasan undang-undang fatwa, dan keanggotaan dalam Komite Fatwa. Dari segi penegakan keputusan fatwa, Komite-Fatwa Nasional tidak mempunyai yurisdiksi untuk menegakkan suatu fatwa yang telah diputuskan. Hanya Komite Fatwa Negara Bagian yang mempunyai yurisdiksi untuk mewartakan dan menegakkan fatwa di negara masing-masing setelah mendapat ijin DYMM Sultan. Lazimnya fatwa yang diputuskan oleh Komite Fatwa Nasional akan dibahas kembali di tingkat Komite Fatwa Negara Bagian dan komite ini tidak terikat untuk mewarta dan menegakkan fatwa tersebut.

Keadaan seperti ini menyebabkan penyelarasan suatu fatwa tidak dapat dilakukan dan terkesan memerlukan waktu lama untuk diselaraskan. Ada fatwa yang telah diputuskan di tingkat Komite Fatwa Nasional masih belum diambil tindakan oleh Komite Fatwa Tingkat Negara Bagian untuk diwartakan dan ditegakkan di negara masing-masing. Sementara itu terdapat isu dan permasalahan yang menyangkut kepentingan nasional dibahas dan diputuskan di tingkat Komisi Fatwa Negara Bagian seperti hukum berinvestasi di Amanah Saham Nasional (ASN) dan Amanah Saham Bumi putera (ASB), meskipun Komisi Fatwa Nasional hingga kini belum mengambil keputusan mengenai hal itu. Malah terdapat Mufti Negara Bagian yang mengambil keputusan sendiri terkait suatu fatwa yang di keluarkan oleh ulama luar negara bagian tanpa merujuk kepada Komisi Fatwa Nasional yang memutuskan suatu fatwa di tingkat Negara Bagian. 
Dalam hal keanggotaan komisi, masih banyak keanggotaan komisi di isi oleh ulamaulama yang pakar dalam bidang fikih saja, masih kurang melibatkan pihak lain yang mempunyai pengetahuan dankepakaran dalam bidang ilmu-ilmu pengetahuan masa kini untuk menangani permasalahan-permasalahan yang memerlukan banyak disiplin ilmu dan kaidah penelitian ilmiah.

Dalam hal pelanggaran terhadap keputusan fatwa, masih terdapat perbedaan hukuman antara negara-negara bagian. Di negara bagian Perlis mereka yang didapati menghina fatwa apapun yang telah dikeluarkan dengan sah menurut Undang-Undang Pentadbiran Agama Islam dapat dikenakan hukuman denda tidak melebihi tiga ribu ringgit atau penjara selama tidak melebihi satu tahun atau kedua duanya. ${ }^{19}$ Di negara bagian Sembilan apabila ada orang didapati mencela, menghina atau mempermainkan fatwa apapun yang telah dikeluarkan dengan sah oleh Mufti maka ia bersalah dan dapat dihukum dengan hukuman denda tidak melebihi lima ribu ringgit atau penjara tidak melebihi tiga tahun atau kedua-duanya. Sedangkan di negara bagian Perak siapapun yang menghina kewibawaan ataumengingkari, melanggar atau membantah fatwa yang dikeluarkan oleh Mufti adalah bersalah dan dapat dikenakan hukuman denda tidak melebihi dari tiga ribu ringgit atau penjara selama tidak melebihi dua tahun atau keduaduanya. ${ }^{20}$

\section{Kedudukan Fatwa di Mesir}

Mesir salah satu negara yang menjadikan Islam sebagai agama resmi negara, namun demikian dalam konstitusi Mesir juga mengakomodir nilai-nilai agama Ibrahim sebagai agama selain Islam. Untuk itu negara memberikan perlindungan penuh kepada agamaagama yang ada untuk melakukan ritual-ritual ibadahnya dan membangun tempat-tempat ibadah sesuai keyakinan yang dianutnya.

Bila berbicara mengenai fatwa, Mesir merupakan negara yang memiliki fatwa tertua di dunia Islam yang diberi nama Dar al-Ifta' yang didirikan pada tahun 1895 Berdasarkan Keputusan dari Khedive Mesir Abbas Hilmi yang ditujukan kepada Nizharah Haqqaniyyah No. 10 tanggal 21 November 1895. Surat tersebut diterima oleh Nizharah tanggal 7 Jumadil Akhir 1313 nomor 55.

Lembaga fatwa Mesir bertugas untuk mengeluarkan putusan dalam suatu permasalahan yang diminta oleh Mufti Agung Mesir, seperti keputusan tentang vonis mati dan lainnya. Fatwa yang dikeluarkan oleh institusi bersifat universal dan tidak terbatas pada wilayah Mesir saja, akan tetapi dapat dijadikan sebagai referensi di seluruh dunia secara

\footnotetext{
${ }^{19}$ Seksyen 39, Enakmen Jenayah Dalam Syarak (Negeri Perlis) 1991.

${ }^{20}$ Seksyen 16, Enakmen Jenayah Syariah (Negeri Perak) 1992
} 
umum. Sangking kuatnya lembaga fatwa yang ada di mesir sampai -sampai ia dijadikan sebagai salah satu penopang Institusi Islam Mesir. ${ }^{21}$

Dari sejak berdirinya lembaga fatwa Mesir sampai sekarang sudah dipimpin oleh 19 Mufti yang dimulai dari Syekh As-Sunnah An-Nawawi pada 1895-1899 sampai hari ini dipimpin oleh Syekh Sauqy Ibrahim Abdul Karim Alam pada 2013 sampai sekarang. Dalam pengangkatan Mufti, dipilih secara aklamasi oleh pembesar ulama-ulama al-Azhar dengan cara menyaring beberapa nama calon sampai dengan akhir terpilih 1 menjadi Mufti agung.

Adapun struktur Kelembagaan Fatwa Mesir terdiri dari enam bidang, yakni sebagai berikut:

\section{Dewan Fatwa}

Dewan fatwa pertama kali didirikan pada masa Prof. Dr. Ali Jumah yang didasarkan pada pertimbangan begitu banyaknya permasalahan yang terjadi serta mengimbangi banyaknya permohonan fatwa yang datang ke lembaga fatwa Mesir baik secara langsung maupun lewat teknologi. Ditambah lagi dengan antusiasme masyarakat Mesir yang ingin mengetahui hukum-hukum dari masalah yang dihadapi dalam kehidupannya sehari-hari.

Lembaga fatwa terdiri dari anggota dewan fatwa yang sudah dipilih sesuai dengan kualitas keilmuannya sesuai dengan keputusan Mufti Agung Prof. Dr. Ali Jumah. Dewan ini semacam lembaga fiqih karena berkumpulnya para ulama yang berkompeten dalam berbagai bidang, bahkan dialamnya terdapat juga para para peneliti Syariah di pusat riset Islam. Dalam lembaga ini para ulama-ulama syariah menjalin kerjasama pada lembagalembaga riset ilmiah dan lembaga akademik yang ada di Mesir seperti lembaga riset nasional Mesir, Universitas Ain Syams, Dār al-Kutub al-Mișriyah (Perpustakaan Nasional Mesir), Lembaga Layanan Sosial, Bank Sentral dan lain sebagainya.

Dalam mengeluarkan fatwa, dewan fatwa memiliki beberapa bagian sesuai dengan cara penerimaan fatwa antara lain: fatwa-fatwa tulisan, fatwa melalui telepon, dan fatwa melalui internet. Hal ini dilakukan untuk mempermudah para peminta fatwa agar tidak kesulitan dalam hal waktu, tempat maupun biaya.

Pusat Riset Islam

Pusat riset Islam dibangun untuk meneliti berbagai macam permasalahan yang timbul pada era tertentu, karena perkembangan zaman yang semakin maju mengakibatkan semakin banyak dan bervariasinya permasalahan yang ditanyakan oleh masyarakat. Untuk itu riset fatwa ini sangat dibutuhkan pada saat ini karena sangat bermanfaat untuk mempelajari berbagai permasalahan secara mendalam agar dapat mengetahui hukum suatu permasalahan sesuai dengan perkembangan zaman serta mengantisipasi permasalahan baru

${ }^{21}$ Institusi Mesir ditopang oleh 4 lembaga keagamaan yaknial-Azharasy-Syarif, Universitas al-Azhar, Kementerian Wakaf dan Lembaga Fatwa Mesir. 
yang timbul pada masa yang akan datang. Dari itu, lewat reset ini para peneliti akan mendapatkan jawaban atas suatu permasalahan yang disampaikan oleh masyarakat. Adapun dalam pusat riset Islam memiliki beberapa devisi diantaranya: Devisi Riset Keislaman, Definisi Masalah-Masalah Keislaman, Devisi sanggahan terhadap kesalahpahaman, dan Devinisi pemikiran Islam.

\section{Pusat Pelatihan Fatwa}

Pusat pelatihan fatwa bertugas untuk memberikan pelatihan bagi para delegasi dan mahasiswa yang ingin mempelajari bagaimana teknik-teknik dalam menganalisis proses sampai pada mengeluarkan fatwa. Biasanya dalam pelatihan ini mahasiswa atau delegasi asing akan melalui beberapa tahap seperti: tahap personal, tahap pelatihan formal, tahap penggabungan antara sistem formal dan sistem belajar jarak jauh.

Pusat Terjemah

Pusat terjemah ini bertugas untuk menerjemahkan pertanyaan-pertanyaan yang masuk dari berbagai negara, kemudian diterjemah ke dalam bahasa Arab. Setelah itu pertanyaan akan diproses oleh para dewan fatwa, lalu diputuskan dengan mengeluarkan jawaban fatwa sebagai respon terhadap permasalahn yang ditanyakan. Pusat terjemah kemudian akan bertugas untuk menerjemahkan kembali jawaban tersebut sesuai dengan asal negara yang meminta fatwa.

Pusat Komunikasi dan Fatwa Elektronik

Lembaga ini bertugas untuk memberikan kemudahan bagi si peminta fatwa yang berada di tempat yang jauh, selain itu juga berguna untuk meningkatkan kinerja lembaga fatwa Mesir yang disesuaikan dengan kemajuan ilmu pengetahuan dan teknologi.

Secara umum Lembaga Fatwa Mesir memiliki dua tugas pokok, yaitu tugas keagamaan dan tugas yang berkaitan dengan pengadilan. Tugas keagamaan Lembaga Fatwa Mesir ini mencakup: Menerima pertanyaan dan permohonan fatwa serta menjawabnya dengan berbagai bahasa; Menjawab kesalah pahaman terhadap Islam; Mengeluarkan pernyataan resmi berkenaan dengan masalah keagamaan; Menyusun riset-riset ilmiah; Mengadakan pelatihan fatwa bagi para mahasiswa asing; dan Mengadakan sistem belajar jarak jauh; dan Menentukan permulaan setiap bulan hijriyah.

Sedangkan tugas yang berkaitan dengan pengadilan adalah memberikan pertimbangan syara' kepada pengadilan atas suatu hukuman yang diberikan kepada yang tertuduh. Biasanya dalam kasus ini Mufti Agung akan mempelajari secara mendalam masalah, dengan memeriksa berkas-berkas sejak pertama kali kasus itu diperkarakan. Jika bukti pelanggaran sudah menunjukkan kepastian, maka tidak ada keraguan bagi Mufti Agung untuk menjatuhkan hukuman mati, akan tetapi bila belum terpenuhinya bukti- 
bukti yang memberatkan terdakwa atau masih adanya perbedaan pendapat diantara dewan fatwa, maka vonis mati tidak dapat dikeluarkan.

Dalam kasus yang kedua ini maka yang digunakan oleh Mufti dalam memutuskan sebuah hukuman atas suatu permasalahan adalah berpegang pada kaidah fiqih dalam masalah pidana yang sesuai dengan perkataan Umar bin Abdul Aziz yakni: Kesalahan seorang Imam dalam memaafkan lebih baik dari kesalahan dalam menjatuhkan hukuman, dalam artian apabila tidak ada alasan yang kuat ditambah dengan bukti-bukti data-data yang akurat maka haram mengeluarkan hukuman mati, sampai menemukan bukti yang akurat sebagai syarat untuk memberatkan terdakwa.

Eksistensi lembaga fatwa Dar al-Ifta memiliki posisi yang strategis karena fatwa-fatwa yang dikeluarkan oleh lembaga tersebut kerap kali dijadikan referensi utama bagi umat Islam di seluruh dunia. Banyak diantara fatwa-fatwa yang dikeluarkan oleh ulama-ulama Mesir yang dijadikan sebagai refrensi oleh ummat muslim, khusunya para akademisi di berbagai negara, seperti fatwa Syekh Muhammad Abduh, fatwa Abdul Majid Saleem, fatwa Hasan Makmun, dan masih banyak yang lainnya.

\section{PENUTUP}

Dari uraian singkat di atas menyimpulkan bahwa sifat mengikat dan tidak mengikatnya suatu fatwa tergantung dari kedudukan fatwa dalam sistem pemerintahan dan sistem ketatanegaraan yang dianut oleh suatu negara. Ada lembaga fatwa yang langsung berada di bawah pemeritahan, dan ada juga lembaga fatwa yang berada diluar pemerintaha. Hal ini menjadi sebab utama dari kekuatan hukum sebuah fatwa di masing-masing negara. Biasanya lembaga fatwa yang berada dalam pemerintahan sifatnya fatwanya mengikat, kuat, universal, dan biasanya adanya interpensi dari pihak atas. Beda halnya dengan lembaga fatwa yang ada diluar pemerintahan bersifat tidak mengikat, hukum fatwanya tidak kuat, bersifat subjektif yakni fatwa hanya untuk yang bertanya saja, dan bersifat independen.

\section{DAFTAR PUSTAKA}

Abdullah, Muhammad Hadi, Dalam Al-Hadaf Tahun 1 Bilangan 1, Jabatan Mufti Kerajaan, (Bandar Seri Begawan, 1997), pp.

Ali, Mohammad Daud, Hukum Islam: Pengantar Ilmu Hukum dan Tata hukum Islam di Indonesia Edisi Keenam, (Jakarta : 1998).

Amin, Ma’ruf, Fatwa dalam Sistem Hukum Islam, (Jakarta : Paramuda Advertising, 2008). Aminnuddin, Abdul Qayyuum \& Ramli, Mohd Anuar, Peranan Institusi Fatwa Negara Brunei Darussalam Dalam Menangani Isu-Isu Kepenggunaan Halal, (Conference Paper, September 2015), 6. 
Ansori, Isa, Analisis Kedudukan Fatwa Di Beberapa Negara Muslim: (Malaysia, Brunei Darussalam dan Mesir), Volume 3, Nomor 1, Juni 2017.

Dain, Japar bin Mat, Institusi Fatwa: Peranan dan Sumbangan Jabatan Mufti Kerajaan Negara Brunei Darussalam, Disertasi Dihadapkan Untuk Ijazah Sarjana Syariah Akademi Pengajian Islam Universiti Malaya Kuala Lumpur, (Kuala Lumpur : Bahagian Pengajian Syariah Akademi Pengajian Islam Universiti Malaya Kuala Lumpur Malaysia, 1999).

J.N.D. Anderson, Hukum Islam di Dunia Muslim, terj. Machnun Husein, cet. I Surabaya: CV. Amapress, 1991.

Najib, Ainun, Fatwa Majelis Ulama Indonesia Dalam Perspektif Pembangunan Hukum Responsif, (Jurnal: Volume 4, No. 2, Desember 2012).

Pehin Jawatan Luar Pekerma Raja Dato Seri Utama Dr. Ustaz Haji Awang Mohd Zain Bin Haji Serudin, Brunei Sebuah Negara Islam: Latar Belakang Keislamannya, (Akademi Pengajian Brunei Universiti Brunei Darussalam ; Bandar Seri Begawan, 1996).

Qardawi, Yusuf, Al-Ijtihad, Fi Al-Isyarah Al-Islamiyah Ma’a Nadzariyyat Tahliliyyah Fi AlIjtihad Al-Mu'ashir, cet 1, (Kuwait : Dar al-Qalam, 1996).

Rang Undang-Undang Pentadbiran Agama Islam Negeri (Wilayah-Wilayah Persekutuan), Pasal 36 (1) hingga (9).

Seksyen 16, Enakmen Jenayah Syariah (Negeri Perak) 1992

Seksyen 39, Enakmen Jenayah Dalam Syarak (Negeri Perlis) 1991.

Yasin, Mohd. Mohadis, "Pengurusan dan Penyelarasan Fatwa: Pelaksanaan dan Cabaran di Malaysia” (Jurnal Pengurusan dan Penyeledikan Fatwa (JFMR), Vol. 1, 2007).

Yunus, Abdul Hamid Yusoff (1991) "Ijtihad dan Amalannya dalam Pembinaan Fatwa di Malaysia”, (Latihan Ilmiah Sarjana Pengajian Islam, Akademi Pengajian Islam, Universiti Malaya). 